\title{
膝後十字䩲帯損傷の予後について
}

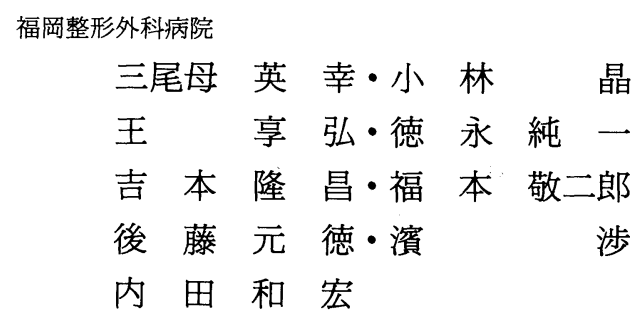

\section{The Long-Term Results of Posterior Cruciate Ligament Injuries}

by

\author{
Hideyuki Miomo, Akira Kobayashi, Toshihiro Oh, \\ Junichi Tokunaga, Takamasa Yoshimoto, Keijiro Fukumotow, \\ Motonori Goto, Wataru Hama and KazuhiroUchida \\ Fukuoka Orthopaedic Hospital, Fukuoka Japan
}

\begin{abstract}
The Long-term results of 23 patients with isola-ted posterior cruciate Ligament(PCL)injuries and 28 patients with PCL complex injuries were evaluated. In the isolated PCL injuries, the over-all result of the group treated conservatively was better than that of the operatively treated. The functional results had no relation to the degree of ligamentous laxity, but had intimate relation to the torque of quadriceps muscle. PCL injuries would cause a relatively slight roentgenographic osteoarthritis however, meniscectomy, if added, hastens the osteoarthritic change. The authors think that for the isolated PCL injuries the conservative treatment is recommended and for the complex injuries the primary repair or reconstruction of PCL would be more advisable.
\end{abstract}

\section{はじめに}

膝後十字勒帯(以下 PCL と略す) 損傷は交通外傷, スポーツ外傷の増加やさらに診断技術の改善進歩(6)に伴 い増加してきている.しかし PCL の機能13114)について まだ明確でない点がありその治療方法について意見が 別れることが多い.またその不安定性のため将来の関 節症 (以下 $\mathrm{OA}$ ) 変化についても論じられている. 今回 われわれは PCL 損傷膝に対して追跡調查したので報告 する.

対

象

昭和 52 年より 63 年までの間に関節鏡，臨床所見 により診断した剥離骨折例を除く PCL 損傷例は 63 例 で,このうち今回直接検診を行った症例は 51 例であっ
た. 内訳は男性 40 例, 女性 11 例, 年齢は 13 才から 69 才まで平均 28 才であった.受傷よりの経過期間は 1 年 から 16 年までで, 平均 4 年 3 力月であった. 受傷原因 は交通外傷 23 例, スポーツ外傷 18 例, 転落, 転倒が 3 例ずつ, 労災 3 例，その他 1 例であった。このうち PCL 単独損傷は 23 例, 複合損傷は 28 例であった。複 合損傷の内訳は内側々副靱帯 (以下 MCL) との合併例 14 例, 前十字䩚帯 (以下 ACL) との合併 6 例, PCL, $\mathrm{ACL}, \mathrm{MCL}$ の三者損傷例は 4 例, 外側及副靯帯(以下 LCL）との合併例は少なかった（表 1).

$$
\text { 治 療方 法 }
$$

治療方法は単独群の新鮮例 9 例, 陳旧例 5 例に保存 的治療を行った. 一次縫合は 4 例存在したが, 若い活 動性のある者に対して行った以前の症例である．再建 
表 1 損傷鞄帯別症例数

\begin{tabular}{c|c|c|c}
\hline \hline & 新 鮮 & 陳 旧 & 計 \\
\hline PCL 単独損傷 & 14 & 9 & 23 例 \\
\hline PCL 複合損傷 & 21 & 7 & 28 \\
\hline PCL+MCL & 12 & 2 & 14 \\
PCL+ACL & 1 & 5 & 6 \\
PCL+ACL+MCL & 4 & 0 & 4 \\
PCL+LCL & 2 & 0 & 2 \\
PCL+ACL + LCL & 2 & 0 & 2 \\
\hline
\end{tabular}

表 2 治 療 方 法

\begin{tabular}{l|c|c|c|c}
\hline \hline & \multicolumn{2}{|c|}{ PCL 単独 } & \multicolumn{2}{c}{ PCL 複合 } \\
\cline { 2 - 5 } & 新鮮例 & 陳旧例 & 新鮮例 & 陳旧例 \\
\hline \multicolumn{1}{c|}{ 保 存 的 } & 9 & 5 & 6 & 5 \\
\hline 一次縫合 & 4 & 0 & 14 & 0 \\
人工勒帯 & 0 & 0 & 1 & 0 \\
Augustine 法 & 1 & 2 & 0 & 1 \\
Semitendinosus & 0 & 1 & 0 & 0 \\
による再建 & 0 & 1 & 0 & 1 \\
骨切り & &
\end{tabular}
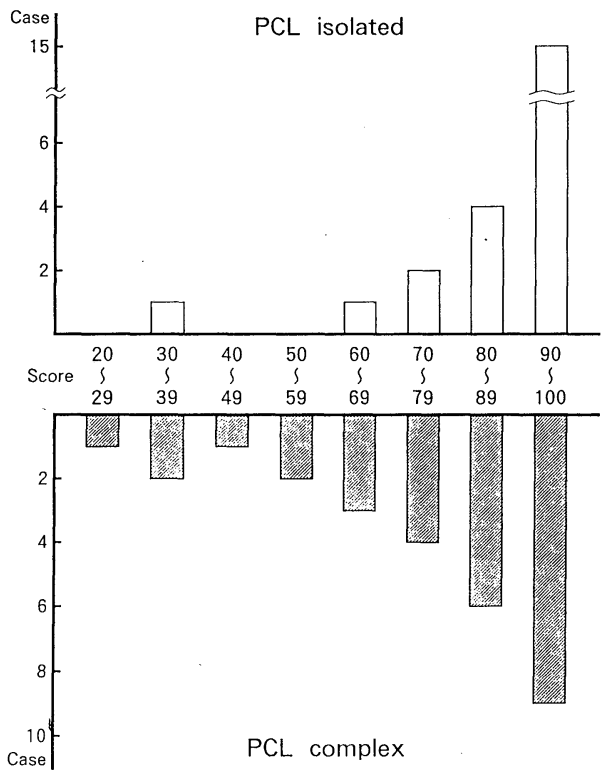

PCL isolated : ave. 86.4

PCL complex : ave. 74.3

有意差あり $(p<0.05)$

図 1 PCL 単独群と複合損傷群との成績比較
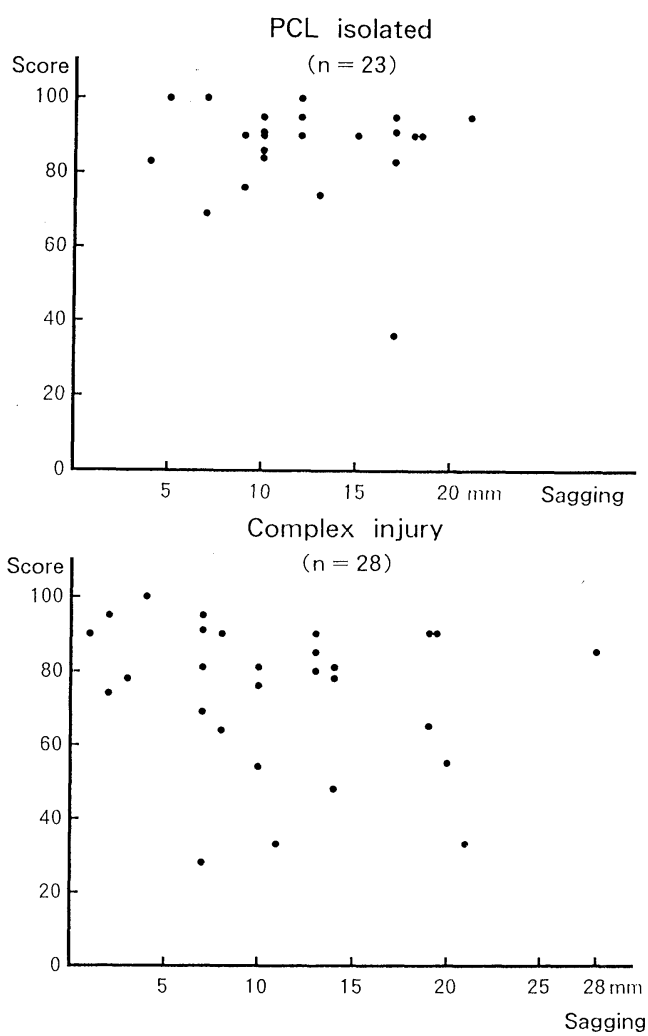

図 2 PCL 単独損傷 複合損傷別の成績と後方動摇 性との関係

術は 4 例存在したがすべて 7 年以上前の症例である. 複合損傷群では新鮮例 14 例に一次縫合, 6 例に保存的 治療を行ったが，その 6 例は靶帯の弛緩だけの場合や growth plate が残存していた症例であった（表 2 ).

\section{調査方法および結果}

治療成績は日整会の膝靶帯損傷治療成績判定規準を 用い評価した．筋力は Cybex II を用い $60^{\circ} / \mathrm{sec}$ の筋卜 ルクを測定し, 脛骨の後方動摇性は緒方の方法 ${ }^{11)}$ を用 い計測した.OA の程度は北大の判定規準を用い評価し た。

治療成績は単独損傷群では 90 点以上が 15 例存在し 平均 86.4 点と高かったが, 複合損傷では 60 点以下が 6 人存在し平均 74.3 点と有意に成績が劣っていた （図 1) さらに単独損傷内で保存的群と手術群との間 で成績を比較すると, 保存的群は平均 90.9 点と有意差 をもち手術群の平均 78.1 点より秀れていた。

次に後方動摇性と成績との相関を調べると単独損傷 
群，複合損傷群ともに症例は広く分散し有意な相関は 認められなかった（図 2)。

大腿四頭筋力と成績との関係をみると逆に単独損傷 群では相関係数 0.744 と強い正の相関があり，また複 合損傷群でも相関係数 0.544 と有意な正の相関を認め た(図 3 ).

受傷後経過年数とOA との関係を調べたが加令によ る OA 変化の影響があると思われる 41 才以上の症例は 除外した。単独損傷群では 20 例中 5 例, $25 \%$ に OA 変 化を認めたが 4 例は stage I で, stage IIIの症例は脛骨 顆部骨折を合併していた。複合損傷群では 19 人中 10 人 $53 \%$ OA を認め, 単独損傷群より頻度が高かった。 その中で半月板切除群は早期より OA 変化を起こした ものが多かった（図 4).

\section{症例}

症例 $1: 21$ 才, 女性.

バイクで転倒した左膝前面を打撲し受傷, PCL 断裂
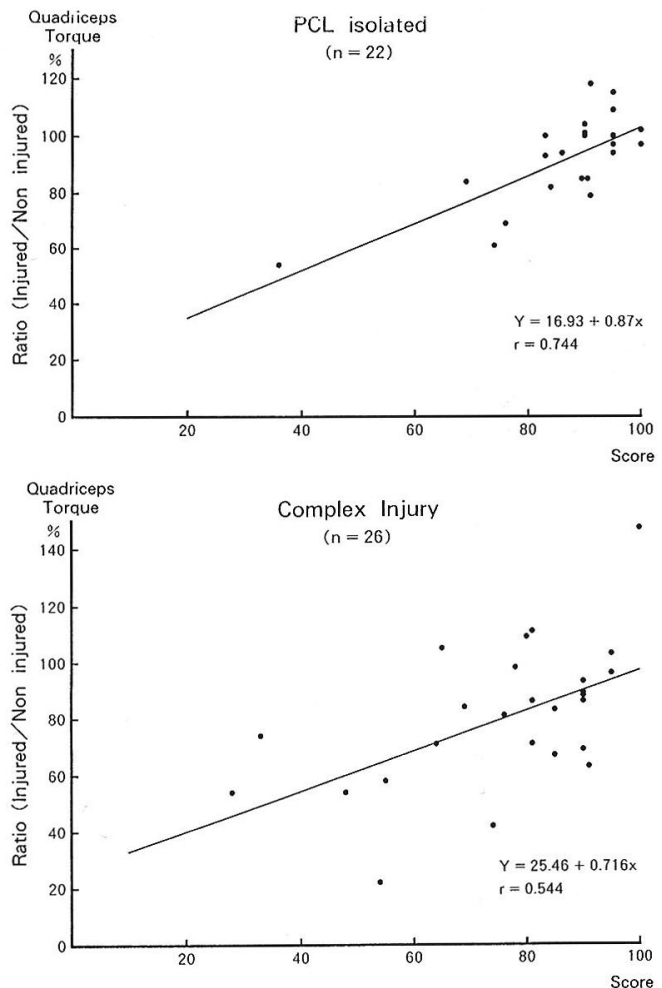

図 3 PCL 単独損傷 複合損傷別の四頭筋トルクと成 績との関係
と内側半月板辺縁剝離を認め, 共に保存的治療を行っ た. 2 年後の現在後方動摇性 $18 \mathrm{~mm}$ 認めるも大腿四頭 筋力は健側の $85 \%$ 存在し, X線変化なく,成績も 90 点 で満足度は高い(図 5 ).

症例 $2: 29$ 才, 男性。

バイク運転中転倒し, 右膝内反を強制され受傷, $\mathrm{PCL}$, LCL と外側半月板の断裂を認め, 両靶帯の一次縫合と
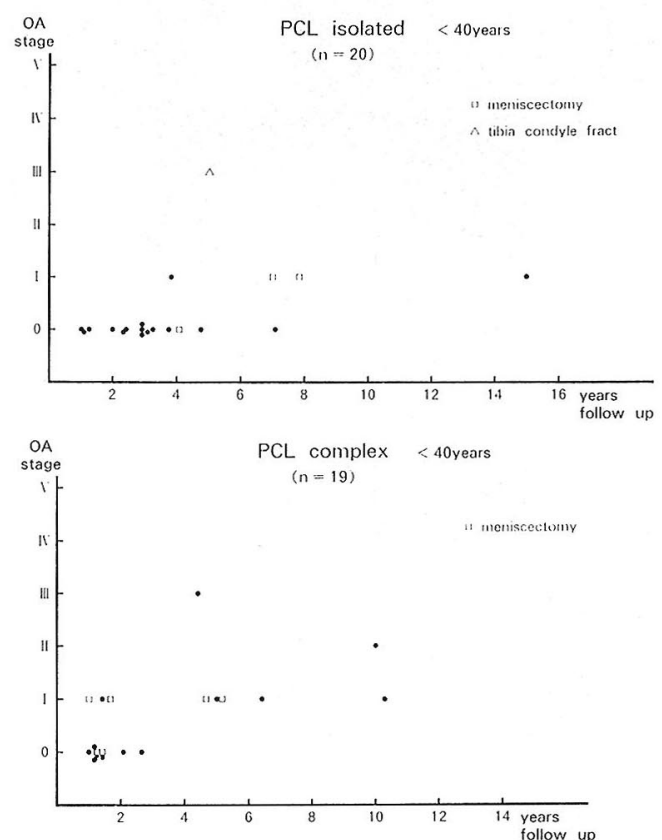

図 4 PCL 単独損傷 複合損傷別の受傷後経過年数 と OA 変化との関係

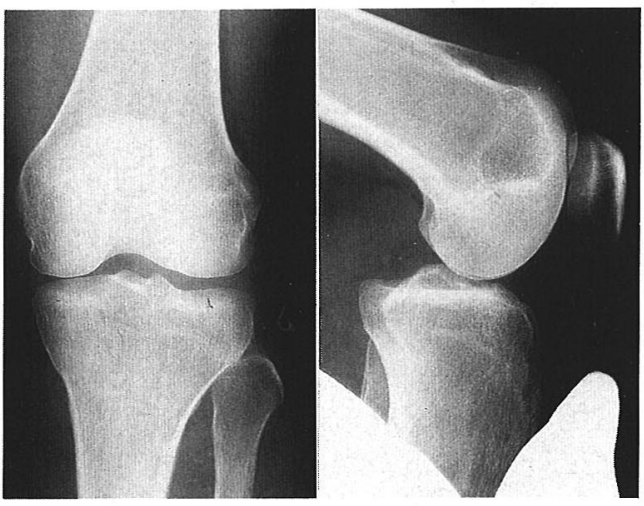

図 5 症例 $1: 21$ 才, 女性. PCL 単独損傷, 保存的治 療, 後方動摇性 $18 \mathrm{~mm}$ 認めるも 2 年後の現在 $\mathrm{OA}$ 変化なく成績 90 点である. 


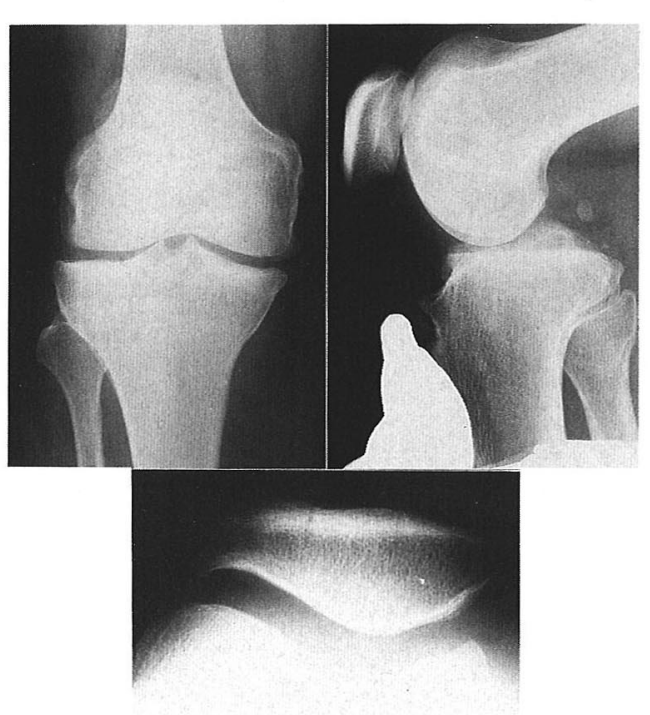

図 6 症例 $2: 29$ 才, 男性. PCL+LCL+外側半月板 損傷で靯帯縫合と半月板切除を行った 5 年後の 現在, 後方動摇性 $28 \mathrm{~mm}, \mathrm{OA}$ 変化も認めるも, 成績 85 点と良好である.

半月板切除術を行った. 5 年後の現在後方動摇性 28 $\mathrm{mm}$ と大きく, stage I の OA 変化を内外側に認める。 しかし大腿四頭筋力は健側比 83 \% 存在し,ソフトボー ルなどのスポーツも十分行え, 成績も 85 点と良好であ る(図6)。

\section{考察}

PCL 損傷, とくに単独損傷においてその治療方法が 問題とされることが多い.Cross ${ }^{2)}$, Dandy ${ }^{3)}$, Fowler ${ }^{4)}$, らは保存的治療で自覚的, 機能的に良好な結果が得ら れたと述べているが，われわれの症例でも保存的治療 群の臨床成績は良好で，かえって手術群よりも秀れて いる. その理由としては術後の膝周囲筋力の低下, 手 術例はすべて PCL の完全断裂だったことなどが考えら れる. しかし単独損傷でも手術的治療を必要とする意 見 $^{10)}$ もあるが, 再建術17) も含め手術により後方動摇性 の静的な安定性の改善が充分に得られないことが問題 である。そのため後方動摇性による将来の $\mathrm{OA}$ 変化も 手術により十分阻止できるかどうか疑問であることを 考えると，単独損傷は新鮮，陳旧ともに保存的治療を 第一選択とするのがよいと思われる ${ }^{9}$.

ここで問題となるのは脛骨の後方動摇性による発生
する関節症変化であるが, われわれの症例では単独損 傷全体では 23 人中 7 人, $30 \%$, 複合損傷全体では 28 人中 17 人, $61 \%$ OA 変化を認めている. 単独群の 7 人中 5 人は $12 \mathrm{~mm}$ 以上の後方動摇性を持っていたこと も考えると動摇性が強いほど OA 変化は出現しやすく なると言える ${ }^{12)}$.しかし OA 変化のあった 15 人中 12 人 は stage Iであったことで PCL 損傷による OA 変化は 比較的軽度であると言える。この関節症変化にもつと も影響する因子は ACL 損傷膝の報告8) にもあるように 半月板切除である。われわれの調査例も半月板切除群 は早期より OA 変化を生じている例が少なくなかった。 PCL 複合損傷の新鮮例ではわれわれは原則として損 傷勒帯の一次修復を行ってきた.Gollehon ${ }^{5)} ら は$ PCL 損傷に LCL, Arcuate ligament が合併するとさらに回 旋不安定性も生じ, 単独損傷では軽度届曲位で安定性 を保っていた㯟が, 軽度届曲位でも不安定になると述 ベている。このように複合損傷では損傷靶帯各自の不 安定性に加え, 相乗効果により新たな不安定性の出現 や, 増大が認められるので一次修復が必要である。幸 い複合損傷の場合 PCL は大腿骨起始部で断裂している ことが多く縫合可能なことが多い. しかし縫合不能例 や陳旧例では, 障害の程度, 年令, 活動性などを検討 し, 再建術も必要である.

後方動摇性と臨床成績との関係は Dandy ${ }^{3)} ら も$ 報告 しているようにほとんど関係は認められなかったのに 対し, 大腿四頭筋力と成績との間には強い相関を認め た.Parolie ${ }^{12)}$ もスポーツ可能で満足度の高い症例は健 側よりも患側の大腿四頭筋のトルクが逆に強いことを 指摘している.したがって PCL 損傷膝の場合, 保存的 治療, 術後のリハビリテーションを行ううえで大腿部 の筋力訓練が非常に重要であると言える。

ところで PCL 単独損傷は ACL 単独損傷と異なり何 故機能的, 自覚的に障害が少ないのであろうか. PCL は主として膝屈曲位において膝の安定性に重要な役割 を果たすが, 動的には届曲位から伸展していく際, 後 方落ち込みを防ぎ, 大腿骨と脛骨との関節面の適合性 を保つ働きがある ${ }^{13)}$.したがって ACL 不全例が軽度屈 曲位付近で giving way などの症状をおこしやすいのと 比べ, PCL 不全例では膝届曲位から伸展する際, とく にその動作の始めに不安定性が生じる。しかし深屈曲 位では, 軽度届曲位と比較して動作中強い力が加わり にくく, 四頭筋を収縮させている状態での膝の運動で は動摇性, 不安定性が減少することなどが PCL 損傷膝 
が比較的機能障害が少ない理由の一つと思われる。

\section{ま と め}

1. PCL 単独損傷 23 例, 複合損傷 28 例について予 後を直接検診した.

2. 単独損傷群の中でも保存的治療群の方が手術群 よりも臨床成績がよい.

3. 単独損傷, 複合損傷群ともに臨床成績は大腿四 頭筋力と密接な関係にあるが, 後方動摇性とはほとん ど相関がない.

4. PCL 損傷膝における経時的 $\mathrm{OA}$ 変化は程度は軽 いが, 半月板切除群, 複合損傷群に比較的多く出現す る.

5. 治療方針は単独損傷の場合は新鮮, 陳旧とも保 存的治療を第一とする. 複合損傷では新鮮例では原則 として一次修復を行うが，陳旧例で障害が強いものに 対しては再建術を行う。

\section{文献}

1) Clancy, W. G. : Treatment of Knee Joint Instability Secodary to Rupture of the Posterior Cruciate Ligament. J. Bone and Joint Surg. 65-A : 310-322, 1983.

2) Cross, M. J. : Long-term followup of posterior cruciate ligament rupture: A study of 116 cases. Am J Sports Med. 12: 292-297, 1984.

3) Dandy, D. J.: The long-term results of unrepaired tears of the posterior cruciate ligament. J. Bone and Joint Surg. 64-B : 92-94, 1982.

4) Fowler, P. J. : Isolated posterior cruciate ligament injuries in athlete. Am J Sports Med. 15 : 553557, 1987.

5) Gollehon, D. L.: The Role of the Posterolateral and Cruciate Ligaments in the Stability of the Human Knee. J. Bone and Joint Surg. 69-A : 223242, 1987.

6) Hughston, J. C. : Classification of Knee Ligament In-stabilities. Part I and II. J. Bone and Joint Surg. 58-A : 159-179, 1976.

7) Hughston, J. C. : Reconstruction of the Posterior Cruciste Ligament. Clin. Orthop. 164: 59-77, 1981.

8）川久保 誠,他：陳旧性前十字靶帯損傷における関節 の変形性変化について (第 2 報) 中部整災誌. $30: 654$ $-656,1987$.

9）小林 晶：膝靱帯損傷における非手術例の予後。臨整 外. $22: 35-47,1987$.

10) Meyers, M. H.: Traumatic Dislocation of the Knee Joint. A Study of Eighteen Cases. J - Bone and Joint Surg. 53-A : 16-29, 1971.
11）緒方公介：後十字靶帯再建における問題点と解決策. 整・災外. $28 ： 273-281,1985$.

12) Parolie, J. M. : Long-term results of nonoperative treatment of isolated posterior cruciate ligament injuries in the athelete. Am J Sports Med. 14 : 35-38, 1986.

13）佐藤 茂, 他; 前後両十字靯带と膝不安定性につい て. 膝. $7: 12,1981$.

14) VanDommelin, B. A. : Anatomy of the posterior cruciate ligament.Am J Sports Med. 17 : 24-29, 1989

\section{質 問州労災病院 井原 秀俊}

PCL 陳旧患者をみると, 大腿四頭筋に対してハムス トリングの筋力低下が著しいのがあるが，先生の症例 では $\mathrm{H} / \mathrm{Q}$ 比のいかんと,成績との関連はどうであった でしょうか.

解 答 福岡整形外科病院 三尾母 英幸 私たちの症例の PCL 損傷患者では, 新鮮例陳旧例と もに $\mathrm{H} / \mathrm{Q}$ 比は平均でほとんど 1：1に近く，また $\mathrm{H} /$ $\mathrm{Q}$ 比と成績との間には特別な相関は認めなかった。

質 問州厚生年金病院 上崎 典雄

(1) PCL 単独損傷はほとんど無いのではないかと思 っている。単独損傷の発生メカニズムは。

(2) ACL が同時に緩んでいる場合があるのでこれ を縫縮することによりわれわれの成績は非常によくな っている.

\section{解 答 福岡整形外科病院 三尾母 英幸}

PCL 損傷メカニズムとしては脛骨前面の打撲や深屈 曲位の強制などが考えられている。この PCL 損傷の場 合，ミクロでとらえれば後方支持組織などの損傷が合 併することは十分考えられるが，実際，臨床的には他 の不安定性を認めず PCL 単独損傷とみなされるものは 多い思われる。

\section{質 問 山口大学 中村 克巳}

PCL 損傷で半月板切除群に OA が多く発生したとの ことですが，損傷時に，半月板とともに軟骨の損傷が あり, OA に進展したのか, 半月板切除により OA が, 発生したのか，どちらと考えておられますか。

\section{解 答 福岡整形外科病院 小林 晶} 従来の repair あるいは再建であまり良い結果が得ら 
れないので, 高位脛骨骨切り術のような位置で線状に

切り，末梢骨片を前方に出すことを考えた。こうする

ことによって大腿四頭筋の効率をよくしようと考えた。

解 答

福岡整形外科病院 三尾母 英幸
PCL 損傷膝の新鮮例に対して全例関節鏡を行った が, 明らかな軟骨損傷が存在したものはなかった. OA の発生はほとんど, 異常動搖性と半月板切除によるも のと思われる。 